\title{
COVID-19, POLICY RESPONSES, AND INDUSTRIAL PRODUCTIVITY AROUND THE GLOBE
}

\author{
Bernard Njindan Iyke*, Susan Sunila Sharma**, and Iman Gunadi*** \\ * Asia-Pacific Applied Economics Association, Australia. Email: bnjindan@gmail.com \\ ** Department of Finance, Deakin Business School, Deakin University, Australia. \\ Email: s.sharma@deakin.edu.au \\ *** Bank Indonesia, Jakarta, Indonesia. Email: i_gunadi@bi.go.id
}

\begin{abstract}
We examine whether the COVID-19-induced policy responses by countries moderated the negative impact of the pandemic on industrial productivity. Using a panel of the 50 most affected countries by the pandemic, we show that the policy responses do not only help reduce the spread of COVID-19, but they also moderate its negative impact on industrial productivity and help steer countries back to their growth paths. We demonstrate that, in the absence of the pandemic, some of the policy responses (i.e., lockdowns, travel restrictions, etc.) would have reduced productivity. We further demonstrate that our estimates are robust when considering alternative specifications of our productivity model. Our study provides strong support for evidence-based policies and emphasizes, consistent with theoretical arguments, that an optimal policy mix is fundamental to steering economies back to their steady productivity growth paths when facing negative shocks.
\end{abstract}

Keywords: COVID-19; Novel coronavirus; Policy response indicators; Industrial productivity. JEL Classifications: I18; E23.

\author{
Article history: \\ Received : : May 27, 2021 \\ Revised : : August 10, 2021 \\ Accepted : September 15, 2021 \\ Available Online: September 30, 2021 \\ https://doi.org/10.21098/bemp.v24i3.1691
}




\section{INTRODUCTION}

The ongoing novel coronavirus (COVID-19) pandemic negatively impacted global financial markets, economies, and social welfare (see Sha and Sharma, 2020; Sharma and Sha, 2020, for an overview). To prevent further damages to economies and financial markets as well as to limit or eradicate the virus, policymakers implemented several policies, including lockdowns, cancellation of public events, face coverings, and fiscal and monetary measures (quantitative easing and fiscal stimulus packages), among others (Phan and Narayan, 2020; Iyke, 2020a). On the academic front, a growing body of research explores the degree of COVID19 's impact and whether these policy responses have been effective in terms of curtailing the negative impact of COVID-19 (see Devpura and Narayan, 2020; Haroon and Rizvi, 2020; Iyke, 2020b; Narayan, 2020a). Despite this, the literature has not explored the role of these policy responses in moderating the impact of COVID-19 on industrial productivity. This is perhaps due to the limited nature of industrial productivity data, which is not available at daily but at lower frequencies. To address this research gap, our study pools countries together to form a panel dataset and uses the resulting dataset to test our hypothesis that the policy responses moderated the impact of COVID-19 on industrial productivity.

Our hypothesis is motivated by the growing literature showing that extreme events like COVID-19 are associated with negative sentiments or extreme uncertainty that can reduce economic and financial activities (Behera and Rath, 2021; Chen et al., 2020; Haldar and Sethi, 2020; Iyke, 2020c, Iyke and Ho, 2021; Salisu and Akanni, 2020). The contagiousness of COVID-19 and the deaths associated with it caused panic and fear. From a theoretical perspective, the adverse information associated with the pandemic causes financial frictions by raising default risk and the cost of borrowing, which hurt investment and productivity (see Bernanke et al., 1999; Christiano et al., 2014). Similarly, the pandemic may also cause people to consume less to save for unexpected events (like infections and deaths), leading to demand shortages, surplus of goods, and low incentive to produce goods (see Basu and Bundick, 2017). The bad news associated with COVID-19 increases the option value of waiting, consistent with irreversibility of investment theory, which reduces productivity (see Bernanke, 1983). In turn, the conducive policy responses like expansionary monetary and fiscal policies, investment in vaccine development, and coordinated efforts to limit the spread of COVID-19, among others, will revitalize economies via boosting consumption and consumer confidence.

To test our hypothesis, we collect monthly data on industrial production indices, policy responses to the coronavirus pandemic, measures of COVID-19 (cases and deaths per million), and conditioning information on the 50 most affected economies by COVID-19 across the globe spanning the period from January 2020 to March 2021. Our main model regresses the annualized growth in the industrial production indices on the lag of COVID-19 related deaths per million, lag of policy response indicators, lag of the interaction of COVID-19 related deaths per million and the policy response indicators, and the lag of the conditioning information. In our robustness checks, we estimate various specifications of this model, including replacing COVID-19 related deaths per million with COVID-19 related cases per million, and using detrended and natural logarithm of industrial production as measures of industrial productivity. 
Our estimations deliver the following findings. First, we show that the COVID-19-induced policy responses across these countries did not only help reduce the COVID-19 spread, but they also succeeded in moderating the negative impact of the pandemic on productivity and revert the economies to positive productivity growth paths. Second, in the absence of the pandemic, some of these policy responses-travel restrictions, bans on social events, lockdowns, etc. - would have hurt industrial productivity in these countries ${ }^{1}$, suggesting that their implementation was timely to mitigate the destructive impact of COVID-19. Third, we demonstrate that these findings are robust using productivity models featuring COVID-19 related cases per million (in place of COVID-19 related deaths per million), and detrended and natural logarithm of industrial production (as measures of industrial productivity). Together, our findings provide support for evidence-based policy responses in times of crises. One implication is that, when negative shocks hit economies, measured policies such as packages to assist businesses, stimulus packages to households to smoothen consumption, small but significant interest rate cuts to reduce the cost of borrowing, etc. are necessary to keep them afloat. Such policies have both immediate and long-term positive spillovers and are social welfare enhancing.

Prior studies have assessed the impact of COVID-19 on various facets of economies and financial markets and whether policy responses mitigate the negative consequences of the pandemic have delivered positive outcomes. For example, COVID-19 caused: a decrease in the labor force participation rate (Bauer and Weber, 2021); a decrease in consumption and investment (Yu et al., 2020); and a contraction in output and credit (Barro et al., 2020; Choi, 2020; Liu et al., 2020). Past studies show that the COVID-19-induced policy responses have a mixed impact on various aspects of the economy. Ashraf (2020) shows that social distancing measures reduced COVID-19 cases and stock market returns, whereas awareness programs, quarantine, and testing policies increased stock market returns. Yang and Deng (2021) finds that government interventions like contact tracing, testing, and social distancing magnified the negative impact of the pandemic on stock returns. Baig et al. (2021) show declining liquidity and stability of stock markets following the implementations of COVID-19 induced lockdowns and other restrictions. Bannigidadmath et al. (2021) demonstrate that COVID-19 related government policies generally have a negative impact on stock markets. Feng et al. (2021) find that the various policies implemented by governments, including public awareness campaigns and restrictions on internal movements reduced COVID-19 induced exchange rate volatility. Similarly, Zaremba et al. (2021) show that government interventions significantly decreased sovereign bond volatility.

Padhan and Prabheesh (2021) provide an extensive survey of the literature. By and large, no study assesses whether the policy responses by countries succeeded in moderating the negative impact of the pandemic on industrial productivity. Our study contributes to the literature in this regard by showing that the policy responses have been effective in moderating COVID-19's impact on productivity. Our analyses also contribute to the literature on the optimal policies in times of

This is true even for economic support packages in normal times because they do not encourage hard work but shift capital to unproductive sectors of the economy. 
crises (see Assenza et al., 2020; Kahn and Wagner, 2021; Mitman and Rabinovich, 2020; Moser and Yared, 2020). It shows that an optimal policy mix (fiscal, monetary, and other policies) is necessary to overcome a crisis. The paper proceeds as follows. In Section II, we detail our data and methodology. Section III presents the results, while Section IV concludes the paper.

\section{DATA AND METHODOLOGY}

A. Data

In this study, we use monthly data of 50 countries severely impacted by the COVID-19 pandemic over the period from January 2020 to March 2021. These 50 countries are listed in Panel B of Table 1. Note that some countries have missing observations on some variables in certain months. Hence, our panel data is unbalanced. We use the annualized growth rate of industrial production indices as our dependent variable (see Panel A of Table 1, for the computation of this variable). The industrial production indices are sourced from the from Bank of Indonesia. We consider the following three groups of datasets as our explanatory variables. The first group of explanatory variables include five proxies of policy response indicators to the pandemic, namely stringency index, stringency legacy index, government response index, containment and health index, and economic support index. Data on all these policy response indices are downloaded from the Blavatnik School of Government database.

The second group of explanatory variables include two measures of the COVID-19 pandemic, namely total number of cases (per million) and total number of deaths (per million) for each country. These COVID-19 measures are sourced from the online published database, namely Our World in Data (see www.ourworldindata.org). The final set of variables used in this study are the following four control variables, namely short-term interest rates, money supply (M2), inflation rate (measured as the growth rate of consumer price index), and stock price. Detail description of all variables considered for this study is given in Panel A of Table 1.

Table 1.

List of Variables and the Selected Countries

This table shows the list of variables - their short, full names, and definitions, where applicable-the sources from which we gathered data on them, and the selected countries.

\begin{tabular}{lcc}
\hline & Panel A: List of Variables & \\
\hline Variable & Full Name & Source(s) \\
\hline $\begin{array}{l}\text { Industrial productivity } \\
\text { variables }\end{array}$ & & \\
IP & Industrial production index & Bank of Indonesia \\
$\Delta \mathrm{IP}$ & Annualised growth rate of IP, which we calculated as $^{\prime}$ & Authors \\
& $\Delta I P_{i, t}=\left[\ln (I P)_{i, t} / \ln (I P)_{i, t, 1}\right]^{*} 100$ for IP $i$ in period $t$. & computation \\
dIP & Authors' \\
& and subtracting the best fit line from IP (or extracting & computation \\
& the error term from the regression). & \\
\hline
\end{tabular}


Table 1.

List of Variables and the Selected Countries (Continued)

\begin{tabular}{|c|c|c|c|}
\hline \multicolumn{4}{|c|}{ Panel A: List of Variables } \\
\hline Variable & Full N & & Source(s) \\
\hline \multicolumn{4}{|c|}{ COVID-19 variables } \\
\hline TC & Total COVID-19 & per million & Our World in Data \\
\hline TD & Total COVID-19 d & s per million & Our World in Data \\
\hline \multicolumn{4}{|c|}{ Policy response variables } \\
\hline SI & $\begin{array}{r}\text { Stringency Index, which } \mathrm{n} \\
\text { lockdown }\end{array}$ & $\begin{array}{l}\text { ures the strictness of } \\
\text { cies. }\end{array}$ & $\begin{array}{c}\text { Blavatnik School of } \\
\text { Government }\end{array}$ \\
\hline SL & $\begin{array}{l}\text { Stringency Legacy Index, } \\
\text { intuition of the original vers } \\
\text { and measures the strictne }\end{array}$ & $\begin{array}{l}\text { h approximates the } \\
\text { f the Stringency Index } \\
\text { lockdown policies. }\end{array}$ & $\begin{array}{c}\text { Blavatnik School of } \\
\text { Government }\end{array}$ \\
\hline GI & $\begin{array}{l}\text { Government Response In } \\
\text { variation of government re }\end{array}$ & $\begin{array}{l}\text { which measures the } \\
\text { se over all indicators. }\end{array}$ & $\begin{array}{c}\text { Blavatnik School of } \\
\text { Government }\end{array}$ \\
\hline $\mathrm{CH}$ & $\begin{array}{r}\text { Containment and Health } \\
\text { containment and health } \\
\text { measures of lockdown c } \\
\text { with others like contact tr } \\
\text { investments in vaccine inv } \\
\text { healthcare ir }\end{array}$ & $\begin{array}{l}\text { x, which measures } \\
\text { cies by combining } \\
\text { es and restrictions } \\
\text { and testing policy, } \\
\text { ents, and short-term } \\
\text { ments. }\end{array}$ & $\begin{array}{c}\text { Blavatnik School of } \\
\text { Government }\end{array}$ \\
\hline ES & $\begin{array}{l}\text { Economic Support In } \\
\text { governments' economic su } \\
\text { income support (stimulus } \\
\text { and businesses impa }\end{array}$ & $\begin{array}{l}\text { which measures } \\
\text { rt like debt relief and } \\
\text { ages) for households } \\
\text { by COVID-19. }\end{array}$ & $\begin{array}{c}\text { Blavatnik School of } \\
\text { Government }\end{array}$ \\
\hline \multicolumn{4}{|c|}{ Conditioning variables } \\
\hline M2 & Money Supply & ad money) & CEIC \\
\hline$\Delta \mathrm{M} 2$ & $\begin{array}{l}\text { Annualised growth rate of } 1 \\
\Delta M 2_{i, t}=\left[\ln (M 2)_{i, t} / \ln (M 2)_{i, t-1}\right.\end{array}$ & $\begin{array}{l}\text { which we calculated as } \\
\text { for M } 2 i \text { in period } t \text {. }\end{array}$ & $\begin{array}{l}\text { Authors' } \\
\text { computation }\end{array}$ \\
\hline IR & Short-term i & est rate & $\begin{array}{l}\text { Bloomberg and } \\
\text { CEIC }\end{array}$ \\
\hline $\mathrm{CP}$ & Consumer price & ex inflation & Bank of Indonesia \\
\hline SP & Stock pri & dex & $\begin{array}{l}\text { Bloomberg and } \\
\text { CEIC }\end{array}$ \\
\hline$\triangle \mathrm{SP}$ & $\begin{array}{l}\text { Annualised growth rate of } \\
\qquad \Delta S P_{i, t}=\left[\ln (S P)_{i, t} / \ln (S P)_{i, t-1}\right]\end{array}$ & $\begin{array}{l}\text { vhich we calculated as } \\
\text { for SP } i \text { in period } t \text {. }\end{array}$ & $\begin{array}{c}\text { Authors' } \\
\text { computation }\end{array}$ \\
\hline \multicolumn{4}{|c|}{ Panel B: Countries } \\
\hline Argentina & Georgia & Malaysia & Serbia \\
\hline Austria & Germany & Mexico & Slovakia \\
\hline Bangladesh & Hungary & Morocco & South Africa \\
\hline Belarus & India & Netherlands & Spain \\
\hline Belgium & Indonesia & Pakistan & Sweden \\
\hline Brazil & Iran (Islamic Republic of) & Panama & Switzerland \\
\hline Bulgaria & Iraq & Peru & Turkey \\
\hline Canada & Israel & Philippines & Ukraine \\
\hline Chile & Italy & Poland & $\begin{array}{l}\text { United Arab } \\
\text { Emirates }\end{array}$ \\
\hline Colombia & Japan & Portugal & United Kingdom \\
\hline Czechia & Jordan & Romania & $\begin{array}{l}\text { United States of } \\
\text { America }\end{array}$ \\
\hline Ecuador & Kazakhstan & Russian Federation & - \\
\hline France & Lebanon & Saudi Arabia & - \\
\hline
\end{tabular}




\section{B. Methodology}

Our approach to examining the hypothesis that the conducive policy responses like expansionary monetary and fiscal policies, investment in vaccine development, and coordinated efforts to limit the spread of COVID-19, among others, will revitalize economies via boosting consumption and consumer confidence is as follows. We first examine whether the industrial productivity of the panel of 50 countries are significantly negatively affected by the COVID-19 pandemic by employing the following regression model:

$$
\Delta I P_{i, t}=\alpha_{0}+\beta_{1} \ln T D_{i, t-1}+\delta X_{i, t-1}^{\prime}+\varepsilon_{i, t}
$$

Next, to examine whether the policies adopted during the pandemic eased the negative effects of COVID-19 on industrial productivity, we estimate the following regression model:

$$
\Delta I P_{i, t}=\alpha_{1}+\varphi_{1} \operatorname{lnT} D_{i, t-1}+\varphi_{2} \ln P o l_{i, t-1}+\varphi_{3} \operatorname{lnTD_{it-1}} * \ln P o l_{i, t-1}+\gamma X_{i, t-1}^{\prime}+\epsilon_{i, t}
$$

In Equations (1) and (2), $\Delta I P_{i, t}$ denotes an annualized growth form of industrial production of country $i$ at time $t$ and $\ln T D$ denotes the total number of deaths per million due to the COVID-19 pandemic. $X_{i, t}{ }^{\prime}$ represents four control variables, namely change in money supple $(\triangle M 2)$, short-term interest rate $(I R)$, inflation rate $(C P)$, and stock returns $(\triangle S P)$. The indicator $\ln P o l$ denotes policy response variables, namely stringency index $(\ln S I)$, stringency legacy index $(\ln S L)$, government response index $(\ln G I)$, containment and health index $(\ln C H)$, and economic support index $(\ln E S)$. The operator $\ln$ denotes that variables considered Equations (1) and (2) are in natural logarithm form and since we have five measures of policy response, we estimate Equation (2) five times by considering each measure at a time in the regression model. Additionally, we estimate Equations (1) and (2) using the fixed-effects estimator (by controlling year and country fixed effects) and cluster standard errors at the country level.

\section{MAIN FINDINGS}

This section is organized into three parts. In the first part, we discuss some key statistical features of the data. The second part of the section explains the findings from the panel regression models discussed in Section II. In the final part of this section, we discuss the robustness check of our main findings.

\section{A. Preliminary Results}

We begin by reporting in Table 2 selected descriptive statistics for variables used in this study. Descriptive statistics are reported for raw variables in Panel A, whereas Panel B reports descriptive statistics of variables in the form considered in regression models, mainly in natural logarithm or growth form. We report mean, maximum and minimum values, and Standard Deviation (SD) for all variables in columns 2 to 5 , respectively. In the final column, we report the number of 
observations for each variable. We note that the mean growth rate of industrial production is negative during the pandemic, while for other variables considered in the study, the mean is found to be positive. We also noted an average of 11,983 positive COVID-19 cases and 300 deaths (per million) are recorded during the pandemic for the panel of 50 countries. Additionally, for all five policy response indicators (namely $S I, S L, G I, C H$, and $E S)$ and four control variables $(M 2, I R, C P$, and $S P$ ) positive mean are reported.

Table 2.

\section{Summary Statistics}

This table shows summary statistics of the variables. These statistics are the mean, maximum, minimum, Standard Deviation (SD), and total observations. $\Delta$ denotes annualized changes (growth) in a variable. In denotes the natural logarithm operator. Panels A and B contain summary statistics of the raw and transformed variables, respectively, computed for a panel of 50 countries over the sample period from January 2020 to March 2021. Note that M2 is in millions in Panel A.

\begin{tabular}{|c|c|c|c|c|c|}
\hline \multirow[b]{2}{*}{ Variable } & \multicolumn{4}{|c|}{ Panel A: Raw Variables } & \multirow[b]{2}{*}{ Observations } \\
\hline & Mean & Maximum & Minimum & SD & \\
\hline IP & 110.427 & 451.720 & 10.943 & 45.555 & 528 \\
\hline TD & 296.672 & 1904.895 & 0.000 & 396.553 & 687 \\
\hline TC & 11983.888 & 115368.576 & 0.000 & 17912.023 & 691 \\
\hline SI & 58.972 & 100.000 & 0.000 & 25.795 & 700 \\
\hline SL & 64.662 & 100.000 & 0.000 & 25.626 & 700 \\
\hline GI & 54.635 & 87.760 & 0.000 & 21.614 & 698 \\
\hline $\mathrm{CH}$ & 55.321 & 89.580 & 0.000 & 21.718 & 700 \\
\hline ES & 50.143 & 100.000 & 0.000 & 32.030 & 697 \\
\hline M2 & 706.535 & 31300.200 & -0.442 & 3884.719 & 610 \\
\hline IR & 2.810 & 40.000 & -0.842 & 4.945 & 602 \\
\hline $\mathrm{CP}$ & 5.653 & 157.859 & -2.890 & 17.138 & 745 \\
\hline SP & 35567.432 & 1904324.000 & 21.000 & 178697.985 & 684 \\
\hline \multicolumn{6}{|c|}{ Panel B: Transformed Variables } \\
\hline$\Delta \mathrm{IP}$ & -0.062 & 202.153 & -189.715 & 17.280 & 478 \\
\hline $\ln \mathrm{TD}$ & 4.077 & 7.553 & 0.000 & 2.388 & 687 \\
\hline $\ln \mathrm{TC}$ & 7.197 & 11.656 & 0.000 & 3.348 & 691 \\
\hline $\ln \mathrm{SI}$ & 3.963 & 4.605 & 1.022 & 0.690 & 675 \\
\hline $\ln \mathrm{SL}$ & 4.088 & 4.605 & 1.273 & 0.606 & 675 \\
\hline $\ln \mathrm{GI}$ & 3.869 & 4.475 & 0.445 & 0.727 & 682 \\
\hline $\ln \mathrm{CH}$ & 3.892 & 4.495 & 0.582 & 0.691 & 684 \\
\hline $\ln \mathrm{ES}$ & 4.064 & 4.605 & 2.526 & 0.413 & 557 \\
\hline$\Delta \mathrm{M} 2$ & 1.136 & 135.751 & -143.630 & 12.818 & 563 \\
\hline$\triangle \mathrm{SP}$ & 0.330 & 49.793 & -60.176 & 8.972 & 633 \\
\hline
\end{tabular}

Next, we read the panel unit root test results from Table 3. More specifically, we test the null hypothesis of "panel unit root" using the Levin, Liu, and Chu (LLC, 2002) and Im, Pesaran, and Shin (IPS, 2003) panel unit root tests. We find that, irrespective of the tests used, our results are consistent for all variables. More specifically, we reject the null hypothesis of panel unit root at $1 \%$ significance level for all variables. This indicates, all variables considered in the panel regression models (discussed earlier in Section II) follow a stationary process. 
Table 3.

\section{Unit Root Test Results}

This table reports the unit root test results. We test for unit roots using the Levin-Lin-Chu (LLC) and Im-Pesaran-Shin (IPS) tests. Panels A and B considered constant only and constant and trend, respectively, in the test regressions. $p$-values are in the parentheses.

\begin{tabular}{lcccc}
\hline & \multicolumn{2}{c}{ Panel A: Constant } & \multicolumn{2}{c}{ Panel B: Constant and Trend } \\
\cline { 2 - 5 } Variable & LLC $(p$-value $)$ & IPS $(p$-value $)$ & LLC $(p$-value $)$ & IPS $(p$-value $)$ \\
\hline$\Delta$ IP & -19.243 & -10.239 & -17.068 & -4.599 \\
$\ln \mathrm{TD}$ & $(0.000)$ & $(0.000)$ & $(0.000)$ & $(0.000)$ \\
& -78.402 & -45.326 & -83.341 & -33.937 \\
$\ln \mathrm{TC}$ & $(0.000)$ & $(0.000)$ & $(0.000)$ & $(0.000)$ \\
& -67.057 & -51.112 & -2.470 & -27.849 \\
$\ln \mathrm{SI}$ & $(0.000)$ & $(0.000)$ & $(0.007)$ & $(0.000)$ \\
& -64.278 & -37.264 & -111.159 & -47.369 \\
$\ln \mathrm{SL}$ & $(0.000)$ & $(0.000)$ & $(0.000)$ & $(0.000)$ \\
& -56.170 & -31.403 & -98.623 & -47.707 \\
$\ln \mathrm{GI}$ & $(0.000)$ & $(0.000)$ & $(0.000)$ & $(0.000)$ \\
& -61.200 & -47.000 & -185.675 & -74.296 \\
$\ln \mathrm{CH}$ & $(0.000)$ & $(0.000)$ & $(0.000)$ & $(0.000)$ \\
& -48.689 & -36.276 & -64.500 & -37.294 \\
$\ln \mathrm{ES}$ & $(0.000)$ & $(0.000)$ & $(0.000)$ & $(0.000)$ \\
& -9.531 & -4.250 & -15.742 & -3.496 \\
$\mathrm{M} 2$ & $(0.000)$ & $(0.000)$ & $(0.000)$ & $(0.000)$ \\
$\mathrm{IR}$ & -15.417 & -13.704 & -20.760 & -12.274 \\
& $(0.000)$ & $(0.000)$ & $(0.000)$ & $(0.000)$ \\
$\mathrm{CP}$ & -33.784 & -23.034 & -38.171 & -14.690 \\
& $(0.000)$ & $(0.000)$ & $(0.000)$ & $(0.000)$ \\
& -4.191 & -2.862 & -4.216 & 1.196 \\
& $(0.000)$ & $(0.002)$ & $(0.000)$ & $(0.884)$ \\
& -25.622 & -16.579 & -23.421 & -11.813 \\
& $(0.000)$ & $(0.000)$ & $(0.000)$ & $(0.000)$ \\
\hline
\end{tabular}

\section{B. Empirical Findings}

First, we discuss results reported in Table 4, which we have obtained by estimating Equation (1). Here, we examine whether COVID-19 has a negative effect on industrial productivity of the panel of 50 countries. We estimate Equation (1) five times and report respective results in columns $2-6$. In model 1 , we regress $\triangle I P$ on one period lag of $\ln T D$. This is a baseline model, which contains no control variables. In the remaining four models, we introduce each control variable (namely $\triangle M 2, I R, C P$, and $\triangle S P$ ) one by one to check the robustness of our findings. Overall, we find that COVID-19 pandemic (proxied using one period lag of $\ln T D$ ) has a statistically significant and negative effect on productivity in 3/5 models. In models (1) and (5), we find that $\ln T D$ is statistically insignificant, however the sign is still negative. Thus, we conclude that the industrial productivity of the panel of 50 countries declined due to the COVID-19 pandemic. This is supported by Figure 1, which shows that industrial productivity experienced a decline as the economies recorded substantial growth in COVID-19 deaths. Productivity continued to fall, 
recording a mean growth rate of $-27 \%$ by April 2020, before climbing back to and above the baseline as policymakers bring down COVID-19 deaths towards zero through restrictive measures, extensive awareness campaigns, investment in hospital facilities, etc.

\section{Table 4.}

\section{Impact of COVID-19 on Industrial Productivity}

This table reports the impact of COVID-19 on productivity growth across countries. We regress industrial productivity (measured by annualized IP growth) on lags of $\ln \mathrm{TD}, \Delta \mathrm{M} 2, \mathrm{IR}, \mathrm{CP}$, and $\Delta \mathrm{SP}$. Coefficients and $p$-values are outside and inside parentheses, respectively.

\begin{tabular}{lccccc}
\hline Variable & $\mathbf{( 1 )}$ & $\mathbf{( 2 )}$ & $\mathbf{( 3 )}$ & $\mathbf{( 4 )}$ & $\mathbf{( 5 )}$ \\
\hline Constant & 3.966 & 6.633 & 7.581 & 7.559 & 4.710 \\
& $(0.124)$ & $(0.098)$ & $(0.057)$ & $(0.053)$ & $(0.168)$ \\
$\ln \mathrm{TD}_{\mathrm{it}-1}$ & -1.051 & -1.659 & -1.624 & -1.630 & -0.942 \\
& $(0.124)$ & $(0.097)$ & $(0.080)$ & $(0.090)$ & $(0.201)$ \\
$\Delta \mathrm{M}_{\mathrm{it}-1}$ & & 0.010 & 0.013 & 0.012 & 0.014 \\
$\mathrm{IR}_{\mathrm{it}-1}$ & & $(0.168)$ & $(0.152)$ & $(0.126)$ & $(0.040)$ \\
$\mathrm{CP}_{\mathrm{it}-1}$ & & -0.446 & -0.438 & -0.557 \\
$\Delta \mathrm{SP}_{\mathrm{it}-1}$ & & $(0.246)$ & $(0.261)$ & $(0.131)$ \\
& & & & -0.190 & 1.180 \\
$\mathrm{R}^{2}$ & & & & $(0.846)$ & $(0.245)$ \\
Adjusted $^{2}$ & & & & & 0.157 \\
\end{tabular}

Figure 1.

Industrial Productivity and Growth in COVID-19 Death Dynamics

This figure shows the behavior of mean industrial productivity and mean growth in total COVID-19 deaths per million people for a panel of 50 countries over the sample period from January 2020 to March 2021.

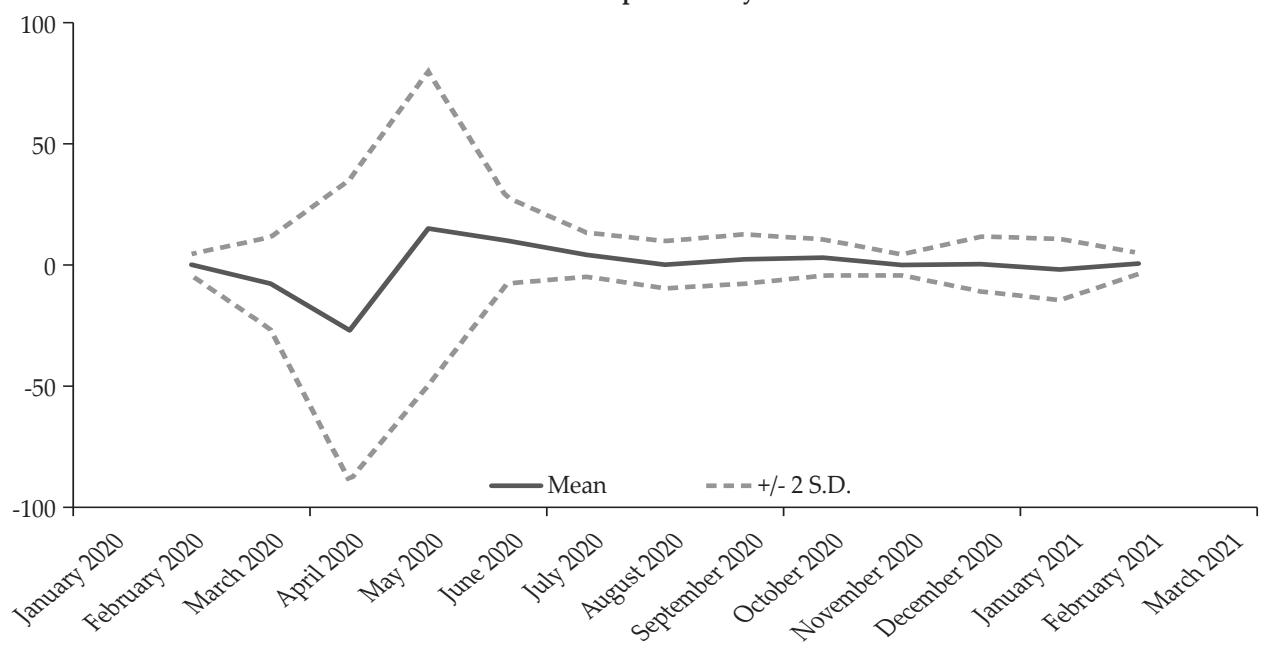


Figure 1.

Industrial Productivity and Growth in COVID-19 Death Dynamics (Continued)

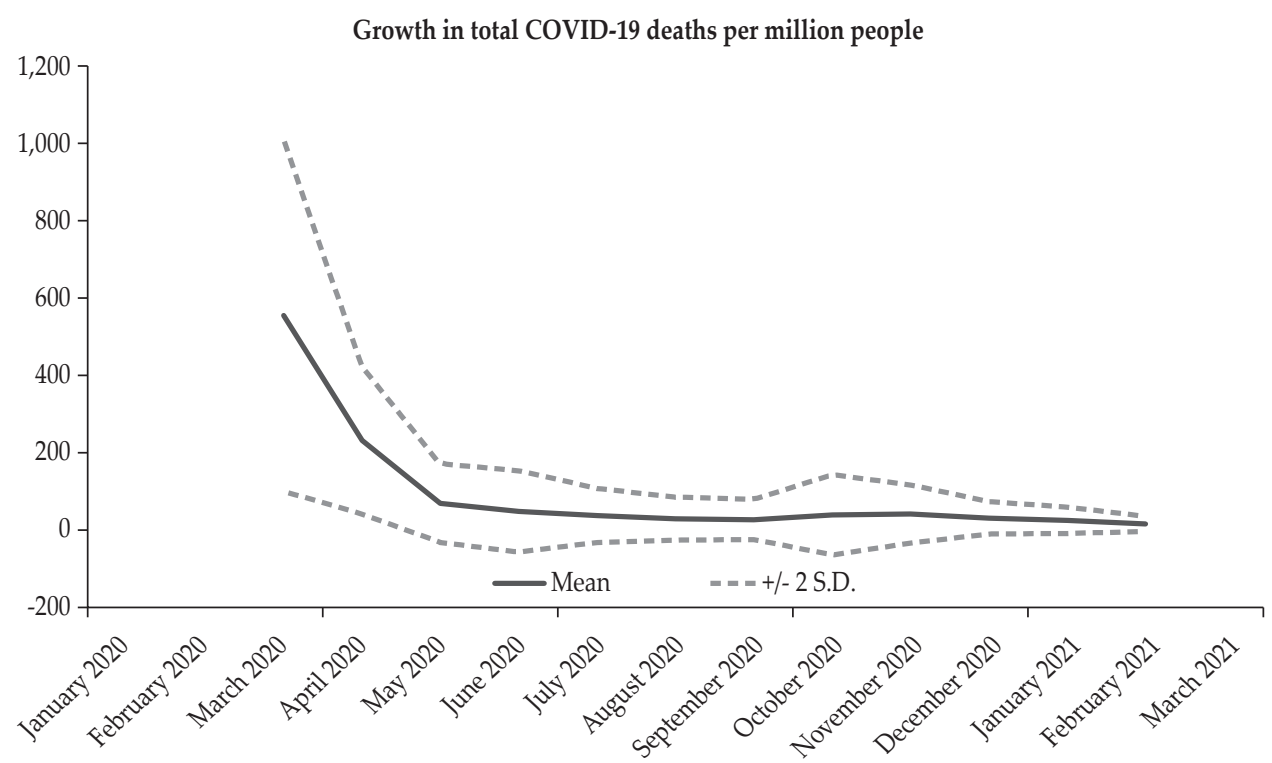

Next, we examine whether the different policies adopted during the pandemic helped eased the negative effects of COVID-19 on industrial productivity by estimating Equation (2). These results are reported in Table 5. Here we consider five different policy response indicators, (namely SI, SL, GI, CH, and ES), and report results in columns $2-6$, respectively. Our findings are as follows. First, we note that $\ln T D$, which proxies the COVID-19 pandemic has a negative and statistically significant effect on productivity. Second, we observe that $\ln P O L$, which captures the effect of the policy responses during the pandemic also has a negative and statistically significant effect on productivity. Our findings are consistent with the use of 4/5 different policy response indicators. The only exception is model 5, whereby we use $E S$ as a proxy for the policy response indicator. It is important to note that the ES index measures governments' economic support like debt relief and income support (stimulus packages) for households and businesses impacted by the pandemic and, therefore, the effect of such policies will have a positive effect on countries productivity. ${ }^{2}$

In the remaining four models, the negative and statistically significant effect of policy responses on industrial productivity is not surprising because these policy response indicators mostly capture very restrictive measures-such as, lockdowns, cancellation of public events, restrictive movements, face covering, and travel bans amongst others - which indeed will not help in boosting the productivity of a country but will help in containing the spread of the virus and should curtail the negative effects of COVID-19 on productivity. Therefore, to

2 For details, see https://www.bsg.ox.ac.uk/research/research-projects/covid-19-governmentresponse-tracker. 
empirically ascertain that the negative effects of the pandemic on productivity can be moderated by imposing different policies, we have included an interaction of COVID-19 measure, $\ln T D$, with the policy response indicators, $\ln P O L$, in Equation (2). We find that the effect of the interaction variable $\left(\ln \mathrm{TD}^{*} \ln \mathrm{POL}\right)$ is positive and statistically significant on productivity of the panel of 50 countries in $4 / 5$ models. Thus, our findings imply that imposing such restrictive policies during the pandemic does not only help reduce the spread of the virus but also helps dilute the negative effects of the pandemic on countries industrial productivity. The only exception is model 5, where the sign of the interactive variable is negative. As we mentioned earlier, the policy indicator, ES index, measures governments' economic support like debt relief and income support (stimulus packages) for households and businesses impacted by the pandemic, which means that it should cushion productivity against the negative COVID-19 shock.

Table 5.

\section{The Role of Policy Responses}

This table shows empirical evidence regarding whether policy responses moderated the impact of COVID-19 on productivity growth across countries. We regress productivity (measured by annualized IP growth) on lags of $\ln$ TD, $\ln \mathrm{POL}, \ln \mathrm{TD} * \ln \mathrm{POL}, \Delta \mathrm{M} 2, \mathrm{IR}, \mathrm{CP}$, and $\Delta \mathrm{SP}$. In Columns (1), (2), (3), (4), and (5), we include policy response indicators SI, SL, GI, CH, and ES, respectively. Coefficients and $p$-values are outside and inside parentheses, respectively.

\begin{tabular}{lccccc}
\hline Variable & $\mathbf{( 1 )}$ & $\mathbf{( 2 )}$ & $\mathbf{( 3 )}$ & $\mathbf{( 4 )}$ & $\mathbf{( 5 )}$ \\
\hline Constant & 38.467 & 39.151 & 37.927 & 41.361 & -39.108 \\
& $(0.007)$ & $(0.002)$ & $(0.000)$ & $(0.000)$ & $(0.002)$ \\
$\ln \mathrm{TD}_{\mathrm{it}-1}$ & -14.354 & -17.736 & -16.000 & -16.376 & 10.944 \\
& $(0.007)$ & $(0.012)$ & $(0.000)$ & $(0.002)$ & $(0.007)$ \\
$\ln \mathrm{POL}_{\mathrm{it}-1}$ & -7.794 & -7.723 & -8.060 & -8.810 & 11.736 \\
& $(0.003)$ & $(0.000)$ & $(0.000)$ & $(0.000)$ & $(0.000)$ \\
$\ln \mathrm{TD}_{\mathrm{it}-1}{ }^{*} \ln \mathrm{POL}_{\mathrm{it}-1}$ & 3.102 & 3.809 & 3.612 & 3.683 & -3.108 \\
& $(0.005)$ & $(0.010)$ & $(0.001)$ & $(0.001)$ & $(0.003)$ \\
$\Delta \mathrm{M}_{\mathrm{it}-1}$ & 0.017 & 0.016 & 0.019 & 0.019 & 0.020 \\
$\mathrm{IR}_{\mathrm{it}-1}$ & $(0.041)$ & $(0.052)$ & $(0.034)$ & $(0.040)$ & $(0.124)$ \\
$\mathrm{CP}_{\mathrm{it}-1}$ & -0.560 & -0.523 & -0.700 & -0.681 & 0.023 \\
$\Delta \mathrm{SP}_{\mathrm{it}-1}$ & $(0.103)$ & $(0.125)$ & $(0.080)$ & $(0.085)$ & $(0.936)$ \\
& 1.040 & 0.903 & 1.209 & 1.168 & 0.172 \\
$\mathrm{R}^{2}$ & $(0.319)$ & $(0.399)$ & $(0.227)$ & $(0.247)$ & $(0.883)$ \\
$\mathrm{Adjjusted}^{2}$ & 0.081 & 0.079 & 0.100 & 0.103 & 0.097 \\
& $(0.350)$ & $(0.373)$ & $(0.240)$ & $(0.232)$ & $(0.352)$ \\
& & & & & \\
& 0.498 & 0.497 & 0.494 & 0.496 & 0.467 \\
& 0.408 & 0.407 & 0.404 & 0.407 & 0.357 \\
\hline
\end{tabular}

\section{Robustness Checks}

In this section, we conduct robustness checks of our earlier reported empirical findings. Our approach is twofold. First, we use a different proxy to capture the effects of the COVID-19 pandemic. More specifically, we use the total number of cases (per million, $\ln T C$ ) instead of $\ln T D$ in Equation (2) as a proxy for the 
pandemic. These results are reported in Table 6. The remaining variables considered in the model remain same, except instead of interacting $\ln T D$ with ln $P O L$, we now consider $\ln T C^{*} \ln P O L$ to capture the combined effects of the COVID-19 pandemic and policy implementations during the pandemic. Our overall findings remain same, and we do conclude that implementing different policies during the pandemic helps in reducing the negative effects of COVID-19 on industrial productivity of the panel of 50 countries.

Table 6.

\section{Using Total Cases per Million as a Measure of COVID-19}

This table shows empirical evidence regarding whether policy responses moderated the impact of COVID-19 (measured in terms of the total number of cases per million) on productivity growth across countries. We regress productivity (measured by annualized IP growth) on lags of $\ln \mathrm{TC}, \ln \mathrm{POL}, \ln \mathrm{TC}{ }^{*} \ln \mathrm{POL}, \Delta \mathrm{M} 2, \mathrm{IR}, \mathrm{CP}$, and $\Delta \mathrm{SP}$. In Columns (1), (2), (3), (4), and (5), we include policy response indicators SI, SL, GI, CH, and ES, respectively. Coefficients and $p$-values are outside and inside parentheses, respectively.

\begin{tabular}{lccccc}
\hline Variable & $\mathbf{( 1 )}$ & $\mathbf{( 2 )}$ & $\mathbf{( 3 )}$ & $\mathbf{( 4 )}$ & $\mathbf{( 5 )}$ \\
\hline Constant & 35.311 & 37.851 & 35.269 & 38.185 & -65.307 \\
& $(0.000)$ & $(0.000)$ & $(0.000)$ & $(0.000)$ & $(0.000)$ \\
$\ln \mathrm{TC}_{\mathrm{it}-1}$ & -7.092 & -9.353 & -7.298 & -7.494 & 9.852 \\
$\ln \mathrm{POL}_{\mathrm{it}-1}$ & $(0.000)$ & $(0.000)$ & $(0.000)$ & $(0.000)$ & $(0.002)$ \\
& -7.680 & -7.897 & -8.331 & -8.889 & 15.909 \\
$\ln \mathrm{TC}_{\mathrm{it}-1}{ }^{*} \ln \mathrm{POL}_{\mathrm{it}-1}$ & $(0.030)$ & $(0.020)$ & $(0.002)$ & $(0.003)$ & $(0.001)$ \\
$\Delta \mathrm{M}_{\mathrm{it}-1}$ & 1.605 & 2.070 & 1.752 & 1.779 & -2.369 \\
$\mathrm{IR}_{\mathrm{it}-1}$ & $(0.001)$ & $(0.003)$ & $(0.000)$ & $(0.000)$ & $(0.002)$ \\
$\mathrm{CP}_{\mathrm{it}-1}$ & 0.018 & 0.018 & 0.019 & 0.019 & 0.016 \\
$\Delta \mathrm{SP}_{\mathrm{it}-1}$ & $(0.001)$ & $(0.007)$ & $(0.001)$ & $(0.001)$ & $(0.001)$ \\
& -0.617 & -0.594 & -0.744 & -0.734 & -0.110 \\
$\mathrm{R}^{2}$ & $(0.100)$ & $(0.116)$ & $(0.084)$ & $(0.086)$ & $(0.764)$ \\
Adjusted R $^{2}$ & 1.130 & 1.009 & 1.271 & 1.258 & 0.290 \\
\hline & $(0.262)$ & $(0.319)$ & $(0.189)$ & $(0.195)$ & $(0.801)$ \\
& 0.093 & 0.091 & 0.113 & 0.116 & 0.116 \\
& $(0.274)$ & $(0.299)$ & $(0.186)$ & $(0.176)$ & $(0.273)$ \\
& & & & & \\
& 0.491 & 0.492 & 0.488 & 0.489 & 0.463 \\
& 0.400 & 0.401 & 0.398 & 0.399 & 0.352 \\
\hline
\end{tabular}

Next, we consider using two alternative measures of our dependent variable, $\triangle I P$. Motivated by the literature (see Giordani, 2004; Bjørnland and Leitemo, 2009), instead of using annualized growth rate of industrial production, we use linear detrended IP $(d I P)$ and the natural logarithm of $I P(\ln I P)$ as dependent variable in Equation 2, to check the consistency of our results. ${ }^{3}$ Results obtained using detrended $I P$ and natural logarithm of IP are reported in Tables 7 and 8, respectively. We find

3 This is slightly different from differencing the natural logarithm of IP, although both entails removing a trend in the IP series. When detrending IP, we regress IP on the trend and subtract the best fit line from IP (or extract the error term from the regression). Differencing IP entails subtracting the previous value of IP $\left(I P_{t-1}\right)$ from the current value $\left(I P_{t}\right)$. Differencing removes trends but produces non-white noise error terms, whereas detrending by least squares introduces autocorrelations if IP follows a random walk. For a detailed discussion, refer to Chan, Hayya, and Ord (1977). 
that irrespective of the use of different measures of $I P$, our main conclusion does not change. That is, the impact of the pandemic and policy response indicators on productivity remains negative and statistically significant. Besides, the interactive variable, $\ln T D^{*} \ln P O L$, is found to be positive and statistically significant, which again implies that the implementation of different policies during the pandemic curtailed the negative effects of COVID-19 on countries industrial productivity.

Table 7.

Using Detrended IP as a Measure of Industrial Productivity

This table shows empirical evidence regarding whether policy responses moderated the impact of COVID-19 on productivity growth across countries. We regress productivity (measured by detrended IP, dIP) on lags of $\ln T \mathrm{D}$, $\ln \mathrm{POL}, \ln \mathrm{TD} * \ln \mathrm{POL}, \Delta \mathrm{M} 2, \mathrm{IR}, \mathrm{CP}$, and $\Delta \mathrm{SP}$. In Columns (1), (2), (3), (4), and (5), we include policy response indicators SI, SL, GI, CH, and ES, respectively. Coefficients and $p$-values are outside and inside parentheses, respectively.

\begin{tabular}{lccccc}
\hline Variable & $\mathbf{( 1 )}$ & $\mathbf{( 2 )}$ & $\mathbf{( 3 )}$ & $\mathbf{( 4 )}$ & $\mathbf{( 5 )}$ \\
\hline Constant & 0.385 & 0.378 & 0.299 & 0.327 & -0.136 \\
& $(0.040)$ & $(0.032)$ & $(0.048)$ & $(0.064)$ & $(0.457)$ \\
$\ln \mathrm{TD}_{\mathrm{it}-1}$ & -0.117 & -0.143 & -0.144 & -0.127 & 0.018 \\
& $(0.084)$ & $(0.113)$ & $(0.018)$ & $(0.058)$ & $(0.729)$ \\
$\ln \mathrm{POL}_{\mathrm{it}-1}$ & -0.087 & -0.083 & -0.069 & -0.075 & 0.044 \\
& $(0.010)$ & $(0.007)$ & $(0.016)$ & $(0.026)$ & $(0.401)$ \\
$\ln \mathrm{TD}_{\mathrm{it}-1}{ }^{*} \ln \mathrm{POL}_{\mathrm{it}-1}$ & 0.026 & 0.031 & 0.033 & 0.029 & -0.008 \\
$\Delta \mathrm{M}_{\mathrm{it}-1}$ & $(0.048)$ & $(0.082)$ & $(0.008)$ & $(0.036)$ & $(0.582)$ \\
$\mathrm{IR}_{\mathrm{it}-1}$ & $2 . \mathrm{E}-04$ & $2 . \mathrm{E}-04$ & $2 . \mathrm{E}-04$ & $2 . \mathrm{E}-04$ & $2 . \mathrm{E}-04$ \\
$\mathrm{CP}_{\mathrm{it}-1}$ & $(0.076)$ & $(0.067)$ & $(0.045)$ & $(0.066)$ & $(0.136)$ \\
$\Delta \mathrm{SP}_{\mathrm{it}-1}$ & $-4 . \mathrm{E}-04$ & $-1 . \mathrm{E}-04$ & -0.002 & -0.001 & 0.004 \\
& $(0.818)$ & $(0.944)$ & $(0.433)$ & $(0.507)$ & $(0.022)$ \\
$\mathrm{R}^{2}$ & $-5 . \mathrm{E}-05$ & -0.001 & 0.003 & 0.002 & -0.007 \\
Adjusted R $^{2}$ & $(0.995)$ & $(0.921)$ & $(0.765)$ & $(0.793)$ & $(0.559)$ \\
& $1 . \mathrm{E}-04$ & $1 . \mathrm{E}-04$ & $1 . \mathrm{E}-04$ & $2 . \mathrm{E}-04$ & $-2 . \mathrm{E}-04$ \\
& $(0.917)$ & $(0.920)$ & $(0.903)$ & $(0.861)$ & $(0.905)$ \\
& & & & & \\
& 0.825 & 0.824 & 0.823 & 0.823 & 0.833 \\
& 0.793 & 0.792 & 0.791 & 0.791 & 0.797 \\
\hline
\end{tabular}

Table 8.

\section{Using the Natural Logarithm of IP as a Measure of Industrial Productivity}

This table shows empirical evidence regarding whether policy responses moderated the impact of COVID-19 on productivity growth across countries. We regress productivity (measured by the natural logarithm of IP, $\ln I \mathrm{IP}$ ) on lags of $\ln \mathrm{TD}, \ln \mathrm{POL}, \ln \mathrm{TD} * \ln \mathrm{POL}, \Delta \mathrm{M} 2, \mathrm{IR}, \mathrm{CP}$, and $\Delta \mathrm{SP}$. In Columns (1), (2), (3), (4), and (5), we include policy response indicators SI, SL, GI, CH, and ES, respectively. Coefficients and $p$-values are outside and inside parentheses, respectively.

\begin{tabular}{lccccc}
\hline Variable & $\mathbf{( 1 )}$ & $\mathbf{( 2 )}$ & $\mathbf{( 3 )}$ & $\mathbf{( 4 )}$ & $\mathbf{( 5 )}$ \\
\hline Constant & 5.049 & 5.043 & 4.963 & 4.992 & 4.532 \\
& $(0.000)$ & $(0.000)$ & $(0.000)$ & $(0.000)$ & $(0.000)$ \\
$\ln \mathrm{TD}_{\mathrm{it}-1}$ & -0.117 & -0.143 & -0.144 & -0.127 & 0.018 \\
& $(0.084)$ & $(0.113)$ & $(0.018)$ & $(0.058)$ & $(0.729)$ \\
$\ln \mathrm{POL}_{\mathrm{it}-1}$ & -0.087 & -0.083 & -0.069 & -0.075 & 0.044 \\
& $(0.010)$ & $(0.007)$ & $(0.016)$ & $(0.026)$ & $(0.401)$ \\
\hline
\end{tabular}


Table 8.

Using the Natural Logarithm of IP as a Measure of Industrial Productivity (Continued)

\begin{tabular}{lccccc}
\hline Variable & $\mathbf{( 1 )}$ & $\mathbf{( 2 )}$ & $\mathbf{( 3 )}$ & $\mathbf{( 4 )}$ & $\mathbf{( 5 )}$ \\
\hline $\ln \mathrm{TD}_{\mathrm{it}-1}{ }^{*} \ln \mathrm{POL}_{\mathrm{it}-1}$ & 0.026 & 0.031 & 0.033 & 0.029 & -0.008 \\
& $(0.048)$ & $(0.082)$ & $(0.008)$ & $(0.036)$ & $(0.582)$ \\
$\Delta \mathrm{M}_{\mathrm{it}-1}$ & $2 . \mathrm{E}-04$ & $2 . \mathrm{E}-04$ & $2 . \mathrm{E}-04$ & $2 . \mathrm{E}-04$ & $2 . \mathrm{E}-04$ \\
& $(0.076)$ & $(0.067)$ & $(0.045)$ & $(0.066)$ & $(0.136)$ \\
$\mathrm{IR}_{\mathrm{it}-1}$ & $-4 . \mathrm{E}-04$ & $-1 . \mathrm{E}-04$ & -0.002 & -0.001 & 0.004 \\
$\mathrm{CP}_{\mathrm{it}-1}$ & $(0.818)$ & $(0.944)$ & $(0.433)$ & $(0.507)$ & $(0.022)$ \\
$\Delta \mathrm{SP}_{\mathrm{it}-1}$ & $-5 . \mathrm{E}-05$ & -0.001 & 0.003 & 0.002 & -0.007 \\
& $(0.995)$ & $(0.921)$ & $(0.765)$ & $(0.793)$ & $(0.559)$ \\
& $1 . \mathrm{E}-04$ & $1 . \mathrm{E}-04$ & $1 . \mathrm{E}-04$ & $2 . \mathrm{E}-04$ & $-2 . \mathrm{E}-04$ \\
$\mathrm{R}^{2}$ & $(0.917)$ & $(0.920)$ & $(0.903)$ & $(0.861)$ & $(0.905)$ \\
Adjusted R $^{2}$ & & & & & \\
& 0.830 & 0.829 & 0.828 & 0.828 & 0.837 \\
& 0.799 & 0.798 & 0.797 & 0.797 & 0.803 \\
\hline
\end{tabular}

\section{CONCLUSION}

The theory suggests that a negative shock like the COVID-19 would reduce industrial productivity around the globe, and in fact empirical evidence supports this prediction. The pandemic has negatively impacted productivity around the world. In attempt to prevent COVID-19 from further spreading and to tackle its negative ramifications on economies, policymakers introduced various policy measures including lockdowns, bans on public gatherings and events, restrictive movements, face covering, border closures, stimulus packages, interest rate reductions, among others. Prior studies have assessed whether such policy responses mitigated the negative consequences of the pandemic on various macroeconomic and financial activities. However, we have little knowledge regarding whether the policy responses moderated the negative impact of COVID-19 on industrial productivity, in particular.

Our study addresses this research gap by regressing industrial productivity on COVID-19 and policy response indicators and the interaction of these indicators, considering a panel of the 50 most affected countries by the pandemic. We unearth the following findings. First, separately, the pandemic and the policy responses reduced industrial productivity. Absent the pandemic, some of the policy responses (i.e., lockdowns, bans on public gatherings and events, restrictive movements, face covering, border closures, etc.) hurt productivity in these countries and vice versa. Second, these policy responses do not only help reduce the COVID-19 spread, but they also succeed in moderating the negative impact of the pandemic on productivity and revert the economies to a positive productivity growth path. Third, we demonstrate that these findings are robust to, among others, the proxies of industrial productivity, COVID-19, and the policy responses. Our findings provide support for evidence-based policy responses in times of crises. An implication is that, when negative shocks hit economies, measured policies such as packages to assist businesses, stimulus packages to households to maintain smooth consumption, small but significant interest rate 
cuts to reduce the cost of borrowing, etc. are necessary to keep them afloat. Such policies have both immediate and long-term positive spillovers and are social welfare enhancing. From a theoretical standpoint, our findings re-echo the need for an optimal policy mix to maintain economies on a steady growth path as previously documented in the macroeconomic policy literature.

Acknowledgement: An earlier version of this paper was presented on July 2, 2021 at the International Economic Association Online World Congress on the theme "COVID-19 and Monetary Policy". This session was sponsored by Bank Indonesia and jointly organised by Bank Indonesia and the Asia-Pacific Applied Economics Association. Helpful comments and suggestions from conference participants and two reviewers of BMEB are duly acknowledged.

\section{REFERENCES}

Ashraf, B. N. (2020). Economic Impact of Government Interventions During the COVID-19 Pandemic: International Evidence from Financial Markets. Journal of Behavioral and Experimental Finance, 27, 100371. https://doi.org/10.1016/j.jbef.2020.100371

Assenza, T., Collard, F., Dupaigne, M., Fève, P., Hellwig, C., Kankanamge, S., \& Werquin, N. (2020). The Hammer and the Dance: Equilibrium and Optimal Policy During a Pandemic Crisis. Toulouse School of Economics. Accessed at http://publications.ut-capitole.fr/34924/1/wp_tse_1099.pdf

Baig, A. S., Butt, H. A., Haroon, O., \& Rizvi, S. A. R. (2021). Deaths, Panic, Lockdowns and US Equity Markets: The Case of COVID-19 Pandemic. Finance Research Letters, 38, 101701. https://doi.org/10.1016/j.frl.2020.101701

Bannigidadmath, D., Narayan, P. K., Phan, D. H. B., \& Gong, Q. (2021). How Stock Markets Reacted to COVID-19? Evidence from 25 Countries. Finance Research Letters, 102161. https://doi.org/10.1016/j.frl.2021.102161

Barro, R. J., Ursúa, J. F., \& Weng, J. (2020). The Coronavirus and the Great Influenza Pandemic: Lessons from the "Spanish Flu" for the Coronavirus's Potential Effects on Mortality and Economic Activity (No. w26866). National Bureau of Economic Research.

Basu, S., \& Bundick, B. (2017). Uncertainty Shocks in a Model of Effective Demand. Econometrica, 85, 937-958.

Bauer, A., \& Weber, E. (2021). COVID-19: How Much Unemployment was Caused by the Shutdown in Germany? Applied Economics Letters, 28, 1053-1058.

Behera, C., \& Rath, B. N. (2021). The COVID-19Pandemic and Indian Pharmaceutical Companies: An Event Study Analysis. Bulletin of Monetary Economics and Banking, Special Issue 2021, 1-14.

Bernanke, B. S. (1983). Irreversibility, Uncertainty, and Cyclical Investment. The Quarterly Journal of Economics, 98, 85-106.

Bernanke, B. S., Gertler, M., \& Gilchrist, S. (1999). The Financial Accelerator In a Quantitative Business Cycle Framework. Handbook of Macroeconomics, 1, 13411393. 
Bjørnland, H. C., \& Leitemo, K. (2009). Identifying the Interdependence Between US Monetary Policy and the Stock Market. Journal of Monetary Economics, 56, 275-282.

Chan, K. H., Hayya, J. C., \& Ord, J. K. (1977). A Note on Trend Removal Methods: The Case of Polynomial Regression Versus Variate Differencing. Econometrica $45,737-744$.

Chen, C., Liu, L., \& Zhao, N. (2020). Fear Sentiment, Uncertainty, and Bitcoin Price Dynamics: The Case of COVID-19. Emerging Markets Finance and Trade, 56, 2298-2309. https://doi.org/10.1080/1540496x.2020.1787150

Choi, S. Y. (2020). Industry Volatility and Economic Uncertainty Due to the COVID-19 Pandemic: Evidence from Wavelet Coherence Analysis. Finance Research Letters, 37, 101783.

Christiano, L. J., Motto, R., \& Rostagno, M. (2014). Risk Shocks. American Economic Review, 104, 27-65.

Devpura, N., \& Narayan, P. K. (2020). Hourly Oil Price Volatility: The Role of COVID-19. Energy Research Letters, 1, 13683. https://doi.org/10.46557/001c.13683

Feng, G. F., Yang, H. C., Gong, Q., \& Chang, C. P. (2021). What is the Exchange Rate Volatility Response to COVID-19 and Government Interventions? Economic Analysis and Policy, 69, 705-719.

Giordani, P. (2004). An Alternative Explanation of the Price Puzzle. Journal of Monetary Economics, 51, 1271-1296.

Haldar, A., \& Sethi, N. (2020). The News Effect of COVID-19 on Global Financial Market Volatility. Buletin Ekonomi Moneter dan Perbankan, 24, 33-58.

Haroon, O., and Rizvi, S. A. R., (2020) Flatten the Curve and Stock Market Liquidity-An Inquiry Into Emerging Economies. Emerging Markets Finance and Trade, 56, 2151-2161; https://doi.org/10.1080/1540496X.2020.1784716

Im, K. S., Pesaran, M. H., \& Shin, Y. (2003). Testing for Unit Roots in Heterogeneous Panels. Journal of Econometrics, 115, 53-74.

Iyke, B. N. (2020a). The Disease Outbreak Channel of Exchange Rate Return Predictability: Evidence from COVID-19. Emerging Markets Finance and Trade, 56, 2277-2297.

Iyke, B. N. (2020b). COVID-19: The Reaction of US Oil and Gas Producers to the Pandemic. Energy Research Letters, 1, 13912.

Iyke, B. N. (2020c). Economic Policy Uncertainty in Times of COVID-19 Pandemic. Asian Economics Letters, 1. https://doi.org/10.46557/001c.17665

Iyke, B. N., \& Ho, S.-Y. (2021). Investor Attention on COVID-19 and African Stock Returns. MethodsX, 8, 101195. https://doi.org/10.1016/j.mex.2020.101195

Kahn, C. M., \& Wagner, W. (2021). Liquidity Provision During a Pandemic. Journal of Banking \& Finance, 106152. https://doi.org/10.1016/j.jbankfin.2021.106152

Levin, A., Lin, C. F., \& Chu, C. S. J. (2002). Unit Root Tests in Panel Data: Asymptotic and Finite-sample Properties. Journal of Econometrics, 108, 1-24.

Liu, D., Sun, W., \& Zhang, X. (2020). Is the Chinese Economy Well Positioned to Fight the COVID-19 Pandemic? The Financial Cycle Perspective. Emerging Markets Finance and Trade, 56, 2259-2276.

Mitman, K., \& Rabinovich, S. (2020). Optimal Unemployment Benefits in the Pandemic. (June 2020). CEPR Discussion Paper No. DP14915, Available at SSRN: https://ssrn.com/abstract=3638019 
Moser, C. A., \& Yared, P. (2020). Pandemic Lockdown: The Role of Government Commitment (No. w27062). National Bureau of Economic Research.

Narayan, P. K. (2020). Oil Price News and COVID-19-Is There Any Connection? Energy Research Letters, 1, 13176. https://doi.org/10.46557/001c.13176

Padhan, R., \& Prabheesh, K. P. (2021). The Economics of COVID-19 Pandemic: A Survey. Economic Analysis and Policy, 70, 220-237.

Phan, D. H. B., \& Narayan, P. K. (2020). Country Responses and the Reaction of the Stock Market to COVID-19-A Preliminary Exposition. Emerging Markets Finance and Trade, 56, 2138-2150.

Salisu, A. A., \& Akanni, L. O. (2020). Constructing a Global Fear Index for COVID-19 Pandemic. Emerging Markets Finance and Trade, 56, 2213-2230. https://doi.org/10.1080/1540496x.2020.1785424

Sha, Y., \& Sharma, S. S. (2020). Research on Pandemics Special Issue of the Journal Emerging Markets Finance and Trade. https://doi.org/10.1080/1540496X.2020.1795467

Sharma, S.S., \& Sha, Y., (2020) Part A: Special Section on COVID-19 Research, Emerging Markets Finance and Trade, 56, 3551-3553. https://doi.org/10.1080/1540496X.2020.1858617

Yang, H., \& Deng, P. (2021). The Impact of COVID-19 and Government Intervention on Stock Markets of OECD Countries. Asian Economics Letters, 1, 18646. https://doi.org/10.46557/001c.18646

Yu, Z., Xiao, Y., \& Li, Y. (2020). The Response of the Labor Force Participation Rate to an Epidemic: Evidence from a Cross-Country Analysis. Emerging Markets Finance and Trade, 56, 2390-2407

Zaremba, A., Kizys, R., \& Aharon, D. Y. (2021). Volatility in International Sovereign Bond Markets: The Role of Government Policy Responses to the COVID-19 Pandemic. Finance Research Letters, 102011. https://doi.org/10.1016/j.frl.2021.102011 
This page is intentionally left blank 